Artikel Riset

DOI : 10.33751/jf.v10i1.2060
Fitofarmaka Jurnal Ilmiah Farmasi

Vol.10, No.1, Juni 2020 : 65-75

p-ISSN : 2087-9164 e-ISSN : 2622-755X

\title{
EFEK EDUKASI MELALUI BROSUR TERHADAP KONTROL TEKANAN DARAH DAN KEPATUHAN PASIEN HIPERTENSI
}

\author{
Emy Oktaviani ${ }^{1^{*}}$, Oktaviana Zunnita ${ }^{2}$, Marlia Handayani ${ }^{3}$ \\ ${ }^{1,2,3}$ Program Studi Farmasi, Fakultas Matematika dan Ilmu Pengetahuan Alam \\ Universitas Pakuan, Bogor, Indonesia \\ *E-mail:emy.oktaviany@unpak.ac.id
}

Diterima : 1 Juni 2020

Direvisi : 26 Juni 2020

Disetujui : 30 Juni 2020

\begin{abstract}
ABSTRAK
Kepatuhan merupakan salah satu faktor pendukung utama ketercapaian efek terapi pengobatan hipertensi. Ketidakpatuhan pasien hipertensi dalam minum obat dapat meningkatkan morbiditas, mortalitas, dan biaya perawatan. Penelitian ini bertujuan untuk mengetahui pengaruh edukasi melalui brosur terhadap kontrol tekanan darah, kepatuhan minum obat dan faktor-faktor lain yang berhubungan pada pasien hipertensi. Rancangan penelitian ini adalah quasi experimental one group pretest and posttest design secara prospektif. Penelitian ini dilakukan menggunakan responden pasien hipertensi di Puskesmas Babakan Madang yang memenuhi kriteria inklusi. Pengambilan data pretest dan posttest menggunakan kuesioner MMAS-8 dan catatan medis pasien. Responden yang bersedia untuk mengikuti penelitian ditandai dengan adanya informed consent. Penelitian dilakukan dengan melakukan pengisian kuesioner MMAS-8 dengan wawancara, pengukuran tekanan darah, dan dilanjutkan dengan intervensi berupa edukasi melalui brosur. Satu bulan kemudian dilakukan pengisian kuesioner MMAS-8 dengan wawancara kembali dan pengukuran tekanan darah. Hasil penelitian dari 50 responden menunjukkan bahwa edukasi melalui brosur memberikan efek terhadap kontrol tekanan darah dan kepatuhan responden dengan hasil uji statistik menggunakan Wilcoxon Signed Rank Test dengan tingkat kepercayaan $0.0001(p<0,05)$.
\end{abstract}

Kata kunci: Brosur, hipertensi, kepatuhan, tekanan darah

\section{EFFECT OF EDUCATION USING BROCHURE ON BLOOD PRESSURE CONTROL AND ADHERENCE AT HYPERTENSION}

\begin{abstract}
Adherence is one of the main supporting factors of achieving the therapeutic effect of hypertension treatment. Non-adherence can increase morbidity, mortality, and treatment costs. This study aims to determine the effect of education through brochures on blood pressure control and medication adherence to hypertension. The design of this study is a quasi experimental one group pretest and posttest design prospectively. This study was conducted using respondents of hypertension patients at the Babakan Madang Community Health Center which met the inclusion criteria. Pretest and posttest data collection using MMAS-8 questionnaire and patient medical records. People who are willing to take part in this study are marked by informed consent. The study was conducted by filling out the MMAS-8 questionnaire by interview, blood pressure, and
\end{abstract}


continued with an intervention in the form of education through a brochure. One month later the MMAS-8 questionnaire was filled out with re-interviews and blood pressure measurements. From 50 respondents showed that education through the brochure had an effect on blood pressure control and respondent compliance with the results of statistical tests using the Wilcoxon Signed Rank Test $(p<0,05)$.

Keywords: Adherence, blood pressure, brochure, hypertension

\section{PENDAHULUAN}

$\begin{gathered}\text { Menurut } \\ \text { Organisation }\end{gathered}$ (WHO), Health
menyebabkan hampir 8 juta orang
meninggal dalam setiap tahunnya
Prevalensi hipertensi di Indonesia
berdasarkan hasil pengukuran pada umur $\geq 18$ tahun sebesar $34,1 \%$ (Kementerian Kesehatan RI, 2018). Menurut WHO pada tahun 2003, rata-rata kepatuhan pasien pada penyakit kronis di negara maju hanya sebesar $50 \%$, sedangkan pada negara berkembang jumlah tersebut bahkan lebih rendah (WHO, 2003). Persentase tidak rutin minum obat pasien hipertensi di Indonesia sebesar 32,3\% dan alasan tertinggi tidak rutin minum obat adalah merasa sudah sehat $(59,8 \%)$ (Kementerian Kesehatan RI, 2018). Masalah dalam penelitian ini adalah ketidakpatuhan pasien dalam minum obat karena kurangnya informasi yang didapatkan dari tenaga kesehatan terutama tenaga kefarmasian mengenai cara minum obat yang benar serta efek yang timbul bila tidak teratur minum obat. Tingginya beban kerja petugas dalam pelayanan resep di puskesmas, menjadi penyebab pemberian informasi obat (PIO) tidak dapat dilakukan dengan baik (Supardi et al., 2011).

Dua faktor utama agar tercapai tekanan darah yang terkontrol pada pasien hipertensi dalam menjalani pengobatan adalah jenis dan dosis obat yang tepat dan kepatuhan. Kepatuhan pada pasien hipertensi yang telah diberikan terapi antihipertensi selama 1 tahun dilaporkan berada pada kurang dari
50\% (Hill et al., 2011a). Penelitian lain juga menyebutkan bahwa kepatuhan pasien hipertensi berada pada tingkat medium (47\%) hingga rendah $(34,2 \%)$ (Rajpura and Nayak, 2014).

Ketidakpatuhan pasien dalam minum obat dapat menyebabkan ketidaktercapaian efek terapi yang mengakibatkan meningkatnya risiko komplikasi. Banyak faktor yang mengakibatkan seseorang sulit patuh terhadap pengobatan, seperti faktor sosial ekonomi, lingkungan, obat, dan tenaga kesehatan (Burnier, 2017). Salah satu faktor seperti faktor obat, banyaknya jumlah obat yang harus dikonsumsi pasien, kompleksnya regimen terapi, dan multiple dose dalam sehari menjadi hambatan untuk patuh terhadap pengobatan (Egan et al., 2012; Hill et al., 2011b).

Faktor komunikasi tenaga kesehatan kepada pasien juga menjadi faktor yang berpengaruh terhadap kepatuhan minum obat (Gellad et al., 2011). Keterbatasan tenaga kesehatan khususnya tenaga apoteker, dan rendahnya pengetahuan tenaga kesehatan, pasien dan masyarakat tentang hipertensi merupakan penyebab utama tidak terkontrolnya tekanan darah, terutama pada pasien hipertensi di Asia. Edukasi dari tenaga kesehatan dengan model komunikasi dua arah dan kepercayaan pasien terhadap tenaga kesehatan menjadi modal dalam upaya peningkatan kepatuhan. Salah satunya adalah edukasi menggunakan brosur yang dilakukan melalui wawancara dan diskusi sehingga 
memungkinkan komunikasi berjalan dua arah (Burnier, 2017).

Brosur merupakan sumber informasi berisi tulisan dan beberapa gambar tentang suatu topik khusus untuk sasaran dan tujuan tertentu. Kelebihan brosur dalam penelitian ini adalah brosur ini dibuat oleh peneliti sendiri disusun berdasarkan tujuan yang ingin dicapai dalam penelitian yang berkaitan dengan isi kuisioner MMAS-8 dan bersumber dari guideline hipertensi seperti American Heart Association, Joint National Committee-8 dan berbagai sumber lainnya. Beberapa penelitian lain mengenai media edukasi banyak dilaporkan. Rosydah et al. (2015) menyatakan bahwa edukasi menggunakan pil count tidak menunjukkan perbedaan pada pasien diabetes. Namun, penelitian lain menyebutkan bahwa pemberian edukasi melalui konseling dapat meningkatkan kepatuhan pada pasien hipertensi (Swandari et al., 2014). Penelitian ini bertujuan untuk mengetahui efek edukasi melalui brosur yang yang mudah dibawa terhadap tekanan darah dan tingkat kepatuhan minum obat pasien hipertensi.

\section{METODE PENELITIAN Rancangan Penelitian}

Penelitian ini menggunakan rancangan quasi experimental one group pretest and posttest design secara prospektif. Teknik pengambilan sampel dalam penelitian ini menggunakan purposive sampling dengan jumlah sampel minimal 50 responden.

\section{Responden Penelitian}

Kriteria inklusi dalam penelitian ini adalah pasien dengan diagnosa utama hipertensi dengan atau tanpa komplikasi, pasien hipertensi yang berobat ke Puskesmas Babakan Madang dan telah mendapatkan antihipertensi oral minimal 3 bulan terakhir pasien, berusia di atas 20 tahun, serta dapat membaca dan menulis. Kriteria ekslusi dalam penelitian ini adalah pasien yang sedang hamil atau menyusui dan pasien yang tidak melengkapi data penelitian atau mengundurkan diri selama penelitian.

\section{Instrumen Penelitian}

Instrumen yang dipakai dalam penelitian ini adalah adalah kuesioner MMAS-8 (Morisky Medication Adherence Scale-8) yang telah di validasi (Riani et al., 2017), catatan medik pasien di puskesmas, lembar pengumpulan data pasien, guideline Joint National Commitee (JNC) edisi 8 tahun 2017. Pharmacotherapy handbook, dan guideline American Health Asosiation (AHA).

Tahapan Penelitian

a. Penjaringan Penelitian dan Pengambilan Pretest

Tahap penelitian dimulai dengan mengumpulkan responden penelitian yang sesuai dengan kriteria inklusi. Penjelasan proses penelitian dilakukan oleh peneliti. Pasien hipertensi yang bersedia mengikuti penelitian akan menandatangani informed consent sebagai bukti kesediaannya. Tahap berikutnya adalah pengumpulan data awal responden. Setelah itu dilakukan tahap pretest yaitu pengukuran tekanan darah responden oleh petugas puskesmas terkait dan pengisian kuesioner MMAS-8 dengan metode wawancara. Selanjutnya diberikan intervensi berupa pemberian edukasi melalui brosur. 


\section{b. Pengambilan Data Posttest.}

Setelah pemberian intervensi berupa edukasi melalui brosur, satu bulan sejak pemeriksaan tekanan darah dan pemberian edukasi, responden melakukan pengambilan data posttest dengan melakukan pengukuran tekanan darah oleh petugas kesehatan yang terlibat dan pengisian kuesioner MMAS-8 dengan metode wawancara.

\section{c. Analisis Data}

Analisis statistik yang digunakan adalah analisis univariat untuk mendapatkan distribusi frekuensi karakteristik pasien, analisis bivariat untuk menguji efek edukasi melalui brosur terhadap kontrol tekanan darah dan kepatuhan menggunakan
Wilcoxon Signed Rank Test $(p<0,05)$.

d. Etika Penelitian

Penelitian ini telah mendapatkan ethical clearance dari Komisi Etik Universitas Padjajaran dengan nomor registrasi 0219081210 dengan nomor surat 1128/UN6.KEP/EC/2019.

\section{HASIL DAN PEMBAHASAN \\ Karakteristik Responden Penelitian}

Pasien yang tercatat sebagai penderita hipertensi dan rutin melakukan kontrol pengobatan di Puskesmas Babakan Madang adalah 100 orang. Total responden yang memenuhi kriteria inklusi dalam penelitian ini sebesar 50 responden. Karakteristik responden dalam penelitian ini dapat dilihat pada Tabel 1.

Tabel 1. Karakteristik Responden Hipertensi di Puskesmas Babakan Madang

\begin{tabular}{lcc}
\hline \multicolumn{1}{c}{ Variabel } & Frekuensi $(\mathbf{n}=\mathbf{5 0})$ & Persentase $\mathbf{( \% )}$ \\
\hline Usia & 22 & 44 \\
18-60 tahun & 28 & 56 \\
$>60$ tahun & & \\
Jenis Kelamin & 10 & 20 \\
Pria & 40 & 80 \\
Wanita & & \\
Pendidikan & 41 & 82 \\
Rendah & 4 & 8 \\
Menengah & 5 & 10 \\
Tinggi & & \\
Pekerjaan & 37 & 74 \\
Ibu rumah tangga & 4 & 8 \\
Buruh & 1 & 2 \\
Guru & 8 & 16 \\
Swasta & & \\
Kebiasaan Makan & 7 & 6 \\
Asin & 3 & 80 \\
Manis & 40 & \\
Tidak keduanya & & \\
\hline
\end{tabular}


Kelompok usia yang paling banyak menderita hipertensi adalah kelompok umur di atas 60 tahun (56\%) karena pada umur tersebut massa fungsi organ mulai turun atau melemah, sedangkan pada usia muda atau di bawah 60 tahun sebanyak $44 \%$, hipertensi pada usia muda biasanya disebabkan oleh merokok dan pola makan yang tidak sehat. Hasil dari Framinghan Heart Study, pada orang dengan tekanan darah normal pada usia 55 atau 65 tahun, yang diikuti selama 20 tahun, menunjukkan hasil $90 \%$ diantaranya akan menjadi hipertensi pada usia 75 tahun atau 85 tahun (Kaplan \& Weber, 2010).

Responden dalam penelitian ini sebagian besar berjenis kelamin perempuan. Hal ini sejalan dengan hasil RISKESDAS (2017) yang menyatakan prevalensi hipertensi berdasarkan jenis kelamin paling banyak pada wanita $(36,9 \%)$ dibandingkan pria $(31,3 \%)$. Penelitian lain juga menyebutkan bahwa perempuan lebih banyak menderita hipertensi dibandingkan pria (Rosyida, 2015). Hal ini disebabkan oleh penurunan kuantitas hormon estrogen pada wanita seiring bertambahnya usia. Kondisi wanita sebelum menopause dilindungi oleh hormon estrogen yang berperan dalam pencegahan penyakit kardiovaskular. Estrogen juga meningkatkan kadar High Density Lipoprotein (HDL) yang berperan dalam mencegah terjadinya aterosklerosis (Lenfant et al., 2011). Penelitian lain menyebutkan bahwa seiring bertambahnya usia, jumlah reseptor estrogen di dalam darah menurun yang menyebabkan reseptor estrogen alpha $(\mathrm{ER} \alpha)$ juga menurun. Terlihat dari percobaan yang dilakukan pada tikus setelah 12 bulan pasca menopause kadar $\mathrm{ER} \alpha$ menurun. Kadar ER $\alpha$ yang menurun menyebabkan aktivitas dari endothelial nitrit oxide synthase yang berfungi untuk memproduksi nitrit oxide (NO) menurun. Penurunan aktivitas NO ini dapat menyebabkan proses pencegahan terhadap penyakit kardiovaskular ikut menurun (Tarhouni Kahena et al., 2014). Penurunan dari hormon estrogen juga berdampak pada penurunan fungsi diastolik yang mengarah ke hipertensi, fungsi mitokondrial, dan berpengaruh terhadap terjadinya hypertrophy left ventricular (Li \& Gupte, 2017).

Pada tingkat pendidikan, responden paling banyak adalah responden dengan tingkat pendidikan rendah yaitu lulusan sekolah dasar dan pada karakteristik pekerjaan rata-rata responden adalah ibu rumah tangga dan usia lanjut yang tidak produktif lagi. Pada penelitian sebelumnya ditunjukkan bahwa tingkat pendidikan yang dimiliki oleh responden mempengaruhi tingkat pemahaman responden dalam menerima informasi dari tenaga kesehatan. Rendahnya tingkat pendidikan responden dapat mengakibatkan responden sulit dalam menerima sebuah informasi sehingga pengetahuan responden semakin rendah (Mubin et al., 2010). Pada karakteristik kebiasan makan, responden yang paling banyak adalah responden dengan kebiasaan tidak makan makanan asin atau makan makanan manis atau mengurangi keduanya. Sebagian besar responden mengurangi konsumsi makanan asin atau manis setelah terdiagnosa hipertensi. Asupan makanan yang banyak mengandung garam dapat meningkatkan risiko hipertensi (Ravi et al., 2016). Pengurangan asupan garam $2 \mathrm{~g} / \mathrm{hari}$ dapat menurunkan tekanan darah sistolik dan diastolik secara signifikan (Hyseni et al., 2017)

Gambaran Jenis Antihipertensi Oral Pada Responden di Puskesmas Babakan Madang. 
Berdasarkan hasil penelitian terlihat bahwa sebagian besar responden mendapatkan obat antihipertensi tunggal golongan Angiotensin Converting Enzim Inhibitor (ACEI) dengan jenis obat yaitu
Captopril dan golongan Calcium Channel Blocker (CCB) dengan jenis obat yaitu Amlodipin. Untuk data selengkapnya dapat dilihat pada Tabel 2.

Tabel 2. Gambaran Penggunaan Antihipertensi Oral di Puskesmas Babakan Madang

\begin{tabular}{cccc}
\hline Golongan Antihipertensi & Jenis Antihipertensi & Frekuensi (n=50) & Persentase (\%) \\
\hline ACEI & Captopril & 39 & 78 \\
Diuretik Tiazid & Hidroklorotiazid & - & - \\
CCB & Amlodipin & 11 & 22 \\
ARB & Nifedipin & - & - \\
Beta-blocker & Candesartan & - & - \\
\hline
\end{tabular}

Catatan: Data diambil dari ketersediaan obat di Puskesmas Babakan Madang dan persebaran penggunaan jenis antibiotik oleh Puskesmas Babakan Madang. Golongan antihipertensi : ACEI (Angiotensin Converting Enzim Inhibitor), CCB (Calcium Chanal Blocker), ARB (Angiotensin Receptor Blocker)

Jenis obat yang diberikan pada pasien hipertensi pada penelitian ini adalah jenis obat tunggal. Pasien hanya mengkonsumsi satu jenis obat berdasarkan berat atau ringannya hipertensi yang diderita. Penelitian lain menyebutkan bahwa jenis antihipertensi oral yang banyak digunakan adalah golongan ACEI (68\%), diuretik (38\%), dan CCB (28\%) (Uchmanowicz et al., 2018).

Berdasarkan JNC-8 tahun 2017, terapi untuk pasien hipertensi essensial atau hipertensi yang penyebab utamanya tidak diketahui adalah jenis obat tunggal yaitu golongan diuretik yang merupakan terapi pilihan pertama. Selain itu, penggunaan monoterapi ini juga mencegah terjadinya kejadian yang tidak diharapkan. Berdasarkan JNC-8, terapi pilihan pertama pada hipertensi adalah menggunakan terapi tunggal yang disesuaikan dengan kondisi pasien (Ukpabi \& Ewelike, 2017). Namun, beberapa penelitian memang menyarankan untuk menggunakan penggunaan kombinasi untuk mengontrol tekanan darah dan mencegah kejadian yang tidak diharapkan (You et al., 2020).
Penggunaan ACEI sebagai antihipertensi banyak digunakan dalam beberapa kasus hipertensi terlebih jika pasien juga menderita komorbid lain (Rincon-Choles, 2019). ACEI efektif dalam menurunkan kejadian myocardial infarction, menurunkan risiko kematian pada pasien hipertensi, diabetes, dan menurunkan risiko penyakit kardiovaskular (Strauss \& Hall, 2017). Beberapa penelitian menyebutkan bahwa penggunaan ACEI pada pasien hipertensi efektif sebagai obat yang dikombinasikan dengan golongan lain untuk mengontrol tekanan darah pasien (Machado et al., 2017). ACEI juga dapat dikombinasikan dengan golongan diuretik tiazid yang dapat digunakans sebagai terapi kedua pencegahan stroke berulang (Wang et al., 2016). Selain itu, hasil penelitian mengenai perbandingan penggunaan Angiotensin Receptor Blocker (ARB) dengan CCB sama efektifnya dengan penggunaan kombinasi ACEI dan CCB dalam hal menurunkan risiko kejadian rawat inap karena gagal jantung, menurunkan risiko gagal ginjal kronik dan risiko hemodialisis pada pasien 
hipertensi tanpa komorbid penyakit kardiovaskular (Hsiao et al., 2015).

\section{Pengaruh Pemberian Edukasi Melalui Brosur Terhadap Tingkat Kepatuhan Minum Obat Berdasarkan Kuesioner MMAS-8.}

Tabel 3. Pengaruh Pemberian Edukasi Terhadap Kepatuhan Minum Obat Berdasarkan Kuesioner MMAS-8

\begin{tabular}{cccccc}
\hline & \multicolumn{2}{c}{ Pretest } & \multicolumn{2}{c}{ Posttest } \\
\hline \multirow{2}{*}{ Kepatuhan* } & $\begin{array}{c}\text { Frekuensi } \\
(\mathbf{n = 5 0 )}\end{array}$ & $\begin{array}{c}\text { Persentase } \\
(\boldsymbol{\%})\end{array}$ & $\begin{array}{c}\text { Frekuensi } \\
(\mathbf{n}=\mathbf{5 0})\end{array}$ & $\begin{array}{c}\text { Persentase } \\
(\boldsymbol{\%})\end{array}$ & $\boldsymbol{p}^{\text {-Value }}$ (** $^{*}$ \\
\hline Rendah & 50 & 100 & 0 & 0 & \\
Sedang & 0 & 0 & 9 & 18 & 0,0001 \\
Tinggi & 0 & 0 & 41 & 82 & \\
\hline
\end{tabular}

Catatan:. *Tingkat kepatuhan dilihat dari jumlah skor pada kuesioner MMAS-8. Kepatuhan tinggi jika total skor MMAS-8 = 8; kepatuhan sedang jika total skor MMAS-8 = 6 hingga kurang dari 8; kepatuhan rendah jika total skor MMAS-8 = kurang dari 6,**p-Value $=u j i$ Wilcoxon (tingkat kepercayaan 95\%)

Dari Tabel 3 dapat dilihat bahwa perubahan tingkat kepatuhan responden dalam minum obat, dimana tingkat kepatuhan minum obat responden sebelum diberikan edukasi sebagian besar bahkan semua responden menunjukkan kepatuhan rendah $(100 \%)$ dan setelah diberikan edukasi melalui brosur tingkat kepatuhan meningkat menjadi kepatuhan sedang (18\%) hingga tinggi (82\%). Hal ini menunjukkan bahwa edukasi melalui brosur dapat meningkatkan kepatuhan responden dalam meminum obat. Hasil uji statistik menggunakan Wilcoxon Signed Rank Test menunjukkan terdapat perbedaan bermakna tingkat kepatuhan responden sebelum dan sesudah diberikan edukasi $(p<0,05)$. Hasil ini sejalan dengan beberapa hasil penelitian lain yang menyebutkan bahwa edukasi memberikan pengaruh terhadap tingkat kepatuhan pasien hipertensi dalam minum obat dan secara statistik memberikan hasil yang signifikan $(p<0,05)$ (Ayodapo et al., 2020; Bijani et al., 2020; Gaziano et al., 2014).

Edukasi merupakan salah satu upaya meningkatkan kepatuhan responden dalam minum obat. Penelitian ini menguji media edukasi berupa brosur terhadap kepatuhan dan kontrol tekanan darah pasien hipertensi. Brosur ini disusun oleh peneliti dengan menyesuaikan pertanyaan dalam kuesioner MMAS-8 dan dibuat dengan berbagai sumber guideline. Brosur ini berisi apa itu hipertensi, tingkatan hipertensi, berbagai macam obat antihipertensi, juga berisi tips-tips agar tidak lupa minum obat baik pada saat di rumah maupun pada saat berpergian dan apa yang harus di lakukan bila timbul efek samping pada saat mengkonsumsi obat antihipertensi serta komplikasi apa saja yang dapat terjadi jika responden tidak patuh minum obat. Edukasi juga mendukung peningkatan pemahaman terhadap pengobatan yang sedang dijalani, karena pengetahuan dan pemahaman yang rendah juga berperan dalam kepatuhan minum obat. Melalui edukasi pemahaman akan penyakit yang diderita, pengobatan yang dijalani, dan aspek-aspek penting dalam patuh terhadap pengobatan dapat ditingkatkan (Gaffari-fam et al., 2020; Pour et al., 2020). 


\section{Pengaruh Edukasi Melalui Brosur Terhadap Kontrol Tekanan Darah Responden di Puksesmas Babakan Madang.}

Tabel 4. Pengaruh Edukasi Melalui Brosur Terhadap Kontrol Tekanan Darah Responden

di Puksesmas Babakan Madang

\begin{tabular}{|c|c|c|c|c|c|}
\hline \multicolumn{2}{|c|}{ Pretest } & \multicolumn{3}{|c|}{ Posttest } & \multirow[b]{2}{*}{$p$-Value $e^{* * *}$} \\
\hline Tekanan Darah & $\begin{array}{c}\text { Frekuensi } \\
(\mathbf{n}=50)\end{array}$ & $\begin{array}{c}\text { Persentase } \\
(\%)\end{array}$ & $\begin{array}{c}\text { Frekuensi } \\
(\mathbf{n}=50)\end{array}$ & $\begin{array}{c}\text { Persentase } \\
(\%)\end{array}$ & \\
\hline Terkontrol* & 0 & 0 & 43 & 86 & 0,0001 \\
\hline Tidak terkontrol** & 50 & 100 & 7 & 17 & \\
\hline \multicolumn{6}{|c|}{$\begin{aligned} \text { Catatan: } & * \text { Terkontrol jika tekanan darah }<140 / 90 \mathrm{mmHg} \text { untuk usia }<60 \text { tahun dan tekanan darah } \\
& <150 / 90 \mathrm{mmHg} \text { untuk usia }>60 \text { tahun. } \\
& * * \text { Tidak terkontrol jika tekanan darah }>140 / 90 \mathrm{mmHg} \text { untuk usia }<60 \text { tahun dan tekanan darah } \\
& >150 / 90 \mathrm{mmHg} \text { untuk usia }>60 \text { tahun }(\text { Sumber }: \mathrm{JNC}-8,2017) \\
& * * * \text { p } \text {-value }=\text { hasil uji Wilcoxon (tingkat kepercayaan } 95 \%)\end{aligned}$} \\
\hline
\end{tabular}

Tabel 4 menunjukkan data bahwa sebelum intervensi atau pada saat Pretest tekanan darah responden tidak terkontrol yaitu sebanyak $100 \%$. Pada saat Posttest atau setelah intervensi tekanan darah pasien mengalami perubahan dimana terjadi peningkatan kategori tekanan darah terkontrol yaitu sebanyak 43 orang $(86 \%)$. Setelah dilakukan pengujian statistik menggunakan uji Wilcoxon Signed Rank Test diperoleh hasil yang signifikan $(p<0,05)$. Dari hasil tersebut terlihat bahwa terdapat efek pemberian edukasi melalui media brosur terhadap tekanan darah responden berdasarkan pemeriksaan tekanan darah responden di Puskesmas Babakan Madang. Hal ini dikarenakan melalui edukasi responden mendapatkan pengetahuan baru tentang terapi pengobatan hipertensi dan mendapatkan tips agar tidak lupa minum obat antihipertensi yang harus mereka minum setiap hari. Penelitian ini sejalan dengan penelitian yang dilakukan oleh Dewanti (2015) yang menyatakan bahwa pemberian edukasi kepada pasien hipertensi dapat meningkatkan efikasi diri dan kepatuhan pasien minum obat serta menurunkan tekanan darah sistolik dan diastolik secara bermakna. Pemberian edukasi dapat meningkatkan kepatuhan dalam minum obat sehingga dapat meningkatkan kontrol tekanan darah (Pour et al., 2020;Gaffari-fam et al., 2020).

\section{KESIMPULAN}

Edukasi melalui media brosur dapat memberikan efek yang signifikan terhadap kepatuhan minum obat pasien hipertensi dengan nilai signifikansi $0,0001(p<0,05)$ dan ketercapaian efek terapi melalui kontrol tekanan darah pada pasien hipertensi dengan nilai signifikansi $0,0001(p<0,05)$.

\section{SARAN}

Penelitian ini memiliki keterbatasan mengenai analisis faktor-faktor lain yang dapat mempengaruhi kontrol tekanan darah dan kepatuhan. Untuk itu, dapat dilakukan kajian selanjutnya mengenai pengaruh dari faktor-faktor tersebut. Selain itu dapat dikembangkan model sederhana untuk mengawasi kepatuhan minum obat responden selama proses 
pengamatan setelah diberikan intervensi untuk memastikan responden rutin minum obat.

\section{UCAPAN TERIMA KASIH}

Ucapan terima kasih penulis sampaikan kepada Lembaga Penelitian dan Pengabdian Kepada Masyarakat Universitas Pakuan, pihak Puskesmas Babakan Madang, pihak Dinas Kesehatan Kabupaten Bogor, Komisi Etik Universitas Padjajaran, dan pihak terkait lainnya dalam hal penelitian dan publikasi ini.

\section{DAFTAR PUSTAKA}

Ayodapo, A., Elegbede O., Omosanya, O \& Monsudi K. 2020. Patient education and medication adherence among hypertensives in a tertiary hospital, South Western Nigeria. Ethiop J Health Sci, 30: 243-250.

https://doi.org/10.4314/ejhs.v30i2.1 2.

Bijani, M., Tehranineshat B., Ahrari F \& Beygi N. 2020. A Comparison between Multimedia and traditional education in encouraging adherence to treatment regimen in patients with hypertension. The Open Hypertention Journal, 12: 1-6. https://doi.org/10.2174/1876526202 012010001.

Burnier, M. 2017. Drug adherence in hypertension. Pharmacological Research, 125: 142-149. https://doi.org/10.1016/j.phrs.2017. 08.015.

Dewanti, S.W., Andrajati R \& Supardi S. 2015. Pengaruh konseling dan leaflet terhadap efikasi diri, kepatuhan minum obat, dan tekanan darah pasien hipertensi di dua puskesmas Kota Depok. Jurnal Kefarmasian Indonesia, 5: 33-40.
Egan, B.M., Bandyopadhyay D., Shaftman S.R., Wagner C.S., Zhao Y \& Yu-Isenberg K.S. 2012. Initial monotherapy and combination therapy and hypertension control the first year. Hypertension, 59: 1124-1131.

https://doi.org/10.1161/HYPERTEN SIONAHA.112.194167.

Gaffari-fam, S., Babazadeh T., Oliaei S., Behboodi L \& Daemi A. 2020. Adherence to a health literacy and healthy lifestyle with improved blood pressure control in Iran. Patient Prefer Adherence, 14: 499506.

https://doi.org/10.2147/PPA.S2448 20.

Gaziano, T.A., Bertram M., Tollman S.M \& Hofman K.J. 2014. Hypertension education and adherence in South Africa: a cost-effectiveness analysis of community health workers. $B M C$ Public Health 14, 240. https://doi.org/10.1186/1471-245814-240.

Gellad, W.F., Grenard J.L \& Marcum Z.A. 2011. A Systematic Review of Barriers to Medication Adherence in the Elderly: Looking Beyond Cost and Regimen Complexity. The American Journal of Geriatric Pharmacotherapy 9, 11-23. https://doi.org/10.1016/j.amjopharm .2011.02.004.

Hill, M.N., Miller N.H \& DeGeest S. 2011a. Adherence and persistence with taking medication to control high blood pressure. Journal of the American Society of Hypertension 5 , $56-63$. https://doi.org/10.1016/j.jash.2011. 01.001.

Hill, M.N., Miller N.H. \& DeGeest S. 2011b. Adherence and persistence 
with taking medication to control high blood pressure. Journal of the American Society of Hypertension, 5 , 56-63. https://doi.org/10.1016/j.jash.2011. 01.001 .

Hsiao, F.C., Tung Y.C., Chou S.H., Wu L.S., Lin C.P., Wang C.L., Lin Y.S., Chang C.J \& Chu P.H. 2015. Fixed-dose combinations of reninangiotensin system inhibitors and calcium channel blockers in the treatment of hypertension. Medicine (Baltimore), $\quad 94: \quad 51$. https://doi.org/10.1097/MD.000000 0000002355.

Hyseni, L., Elliot-Green A., LloydWilliams F., Kypridemos C., O'Flaherty M., McGill R., Orton L., Bromley H., Cappuccio F.P \& Capewell S. 2017. Systematic review of dietary salt reduction policies: Evidence for an effectiveness hierarchy? PLOS ONE 18(12):5, e0177535. https://doi.org/10.1371/journal.pone .0177535 .

Kementerian Kesehatan RI. 2018. Hasil Utama Riset Kesehatan Dasar 2018. Jakarta.

Lenfant, F., Trémollières F., Gourdy P. \& Arnal, J.F. 2011. Timing of the vascular actions of estrogens in experimental and human studies: Why protective early, and not when delayed?. Maturitas 68(2): 165-173. https://doi.org/10.1016/j.maturitas.2 010.11.016.

Li, S. \& Gupte A.A. 2017. The Role of Estrogen in cardiac metabolism and diastolic function. Methodist Debakey Cardiovasc J. 13(1): 4-8. https://doi.org/10.14797/mdcj-13-14.

Machado, M.A.A., de Moura C.S., Wang Y., Danieli C., Abrahamowicz M.,
Bernatsky S., Behlouli H \& Pilote L. 2017. Comparative effectiveness of antihypertensive drugs in nondiabetic patients with hypertension: A population-based study. The Journal of Clinical Hypertension 19(10): 999-1009. https://doi.org/10.1111/jch.13055.

Mubin, M., Samiasih A \& Hermawati T. 2010. Karakteristik dan pengetahuan pasien dengan motivasi melakukan kontrol tekanan darah di wilayah kerja Puskesmas Sragi 1 Pekalongan. Jurnal Universitas Muhammadiyah Semarang, 6(2).

Pour, E., Aliyari S., Farsi Z., Ghelich Y. 2020. Comparing the effects of interactive and noninteractive education using short message service on treatment adherence and blood pressure among patients with hypertension. Nurs Midwifery Stud, 9(2): 68. https://doi.org/10.4103/nms.nms_82 _19.

Rajpura, J. \& Nayak R. 2014. Medication Adherence in a Sample of Elderly Suffering from Hypertension: Evaluating the Influence of Illness Perceptions, Treatment Beliefs, and Illness Burden. Journal of Manage Care and Pharm, 20(1): 58-65. https://doi.org/10.18553/jmcp.2014. 20.1.58.

Riani, D.A., Ikawati Z., Kristina S.A. 2017. Validasi 8-Item Morisky Medication Adherence Scale Versi Indonesia Pada Pasien Hipertensi Dewasa di Puskesmas Kabupaten Sleman dan Kota Yogyakarta. Tesis Magister Farmasi. Universitas Sanata Darma. Yogyakarta.

Rincon-Choles, H. 2019. ACE inhibitor and ARB therapy: Practical 
recommendations. Cleveland Clinic journal of Medicine, 86: 609.

Rosyida, L., 2015. Kepatuhan Pasien Pada Penggunaan Obat Antidiabetes Dengan Metode Pill Count dan MMAS-8 di Puskesmas Kedurus Surabaya Selatan. Tesis Doktor. Universitas Airlangga. Surabaya.

Strauss, M.H. \& Hall A.S. 2017. Angiotensin receptor blockers do not reduce risk of myocardial infarction, cardiovascular death, or total mortality: further evidence for the ARB-MI paradox. Circulation, 135(22): 2088-2090.

Supardi, S., Herman M.J \& Susyanty A.L. 2011. Kebijakan Penempatan Apoteker Sebagai Pengelola Obat Di Puskesmas. Pusat Teknologi Intervensi Kesehatan Masyarakat, Badan Penelitian dan Pengembangan Kesehatan, Kementerian Kesehatan Republik Indonesia. Jakarta.

Swandari, M.T.K., Puspitasari I., Kusharwanti A.W. 2014. Evaluasi pengaruh konseling farmasis terhadap kepatuhan dan hasil terapi pasien hipertensi di poliklinik penyakit dalam RSUD Cilacap periode Desember 2013-Januari 2014. Jurnal Manajemen dan Pelayanan Farmasi (Journal of Management and Pharmacy Practice) 4: 219-229.

Tarhouni, K., Guihot A.L, Vessières E., Toutain B., Procaccio V., Grimaud L., Loufrani L., Lenfant F., Arnal J.F \& Henrion D. 2014. Determinants of flow-mediated outward remodeling in female rodents. Arteriosclerosis, Thrombosis, and Vascular Biology, 34(6):

1281-1289.
https://doi.org/10.1161/ATVBAHA .114.303404.

Uchmanowicz, B., Chudiak A., Uchmanowicz I., Rosińczuk J., Froelicher E.S. 2018. Factors influencing adherence to treatment in older adults with hypertension. Clin Interv Aging, 13: 2425-2441. https://doi.org/10.2147/CIA.S18288 1.

Ukpabi, O.J. \& Ewelike, I.D. 2017. The eighth joint national committee on the prevention, detection, evaluation, and treatment of high blood pressure (joint national committee-8) report: Matters arising. Nigerian Journal of Cardiology, 14(1): 15-18.

Wang, W.T., You L.K., Chiang C.E., Sung S.H., Chuang S.Y., Cheng H.M., Chen \& C.H. 2016. Comparative effectiveness of blood pressure-lowering drugs in patients who have already suffered from stroke. Medicine (Baltimore), 95(15): $\quad$ e3302. https://doi.org/10.1097/MD.000000 0000003302.

WHO. 2003. Adherence to long-term therapies: evidence for action. World Health Organization. Geneva.

You, S.C., Jung S., Swerdel J.N., Ryan P.B., Schuemie M.J., Suchard M.A., Lee S., Cho J., Hripcsak G., Park R.W \& Park S. 2020. Comparison of first-line dual combination treatments in hypertension: real-world evidence from multinational heterogeneous Cohorts. Korean Circulation Journal, 50(1): 52-68. https://doi.org/10.4070/kcj.2019.01 73. 